\section{Clinical and genetic study of a large Charcot-Marie-Tooth type 2A family from southern Italy}

Article abstract-The authors report a large pedigree from southern Italy with Charcot-Marie-Tooth disease type 2A (CMT2A). The clinical picture was uniform and characterized by distal muscular weakness and atrophy in the lower limbs, reduced or absent tendon reflexes mainly in the lower limbs, and mild sensory impairment in the feet. Significant linkage to the CMT2A locus on chromosome 1p35-p36 was detected. Based on informative recombination in affected individuals, the authors mapped the CMT2A gene between D1S160 and D1S170.

\begin{abstract}
M. Muglia, PhD; M. Zappia, MD; V. Timmerman, PhD; P. Valentino, MD; A.L. Gabriele, PhD; F.L. Conforti, PhD; P. De Jonghe, MD, PhD; M. Ragno, MD; R. Mazzei, PhD; M. Sabatelli, MD; G. Nicoletti, MD; A.M. Patitucci, PhD; R.L. Oliveri, MD, MSc; F. Bono, MD; A. Gambardella, MD; and A. Quattrone, MD
\end{abstract}

Genetic studies have shown that autosomal dominant Charcot-Marie-Tooth (CMT) type 2 (CMT2) is distinct from CMT1 and is genetically heterogeneous. ${ }^{1-9}$ CMT2 loci have been identified on chromosome 1p35-p36 (CMT2A), ${ }^{2-3}$ chromosome 3q13-q22 (CMT2B), ${ }^{4}$ and chromosome 7p14 (CMT2D). ${ }^{5}$ A fourth CMT2 type (CMT2C) has not been linked to any known locus. ${ }^{6}$ Interestingly, distinct point mutations in the myelin protein zero (MPZ) gene also may be responsible for a CMT2-like phenotype. ${ }^{7,8}$ Most recently, a novel CMT2 locus (CMT2E) has been reported on chromosome $8 \mathrm{p} 21$, and a disease-causing mutation was found in the neurofilament light gene. $^{9}$

Until now, significant evidence for linkage to chromosome 1p35-p36 was reported only for five CMT2A families, from Japan or North America, ${ }^{2,3}$ making it difficult to assess the geographic distribution and clinical features of this disorder. Identification of additional pedigrees with CMT2A would allow better results.

In this study, we report a multigeneration Italian kindred with CMT2, and describe the clinical, electrophysiologic, and neuropathologic findings, and the natural clinical history of the disease. We also report linkage to the CMT2A locus on chromosome 1p35-p36.

Family and methods. Family. The CMT2 family originated from Calabria, southern Italy. There were 51 individuals in five generations (figure). Seventeen affected individuals were identified (two died before the initiation of the study, three were not examined, and the remaining

From the Institute of Experimental Medicine and Biotechnology (Drs. Muglia, Gabriele, Conforti, Mazzei, Patitucci, Oliveri, Gambardella, and Quattrone), National Research Council, Piano Lago di Mangone-Cosenza; Institute of Neurology (Drs. Zappia, Valentino, Oliveri, Bono, Gambardella, and Quattrone), School of Medicine, Catanzaro; Institute of Neurology (Dr. Ragno), Hospital G. e C. Mazzoni, Ascoli Piceno; Institute of Neurology (Dr. Sabatelli), Catholic University, Rome, Italy; and Flanders Interuniversity Institute for Biotechnology (VIB) (Dr. Timmerman), Born-Bunge Foundation (BBS), University of Antwerpen (UIA), Antwerpen, Belgium.

Received February 21, 2000. Accepted in final form September 12, 2000

Address correspondence and reprint requests to Prof. Aldo Quattrone, Cattedra ed U.O. di Neurologia, Facoltà di Medicina e Chirurgia "Magna Graecia," Via Tommaso Campanella, 88100 Catanzaro, Italy; e-mail: neurol.unicz@ interbusiness.it
12 were available for the study). The youngest generation contains seven individuals whose disease status is unknown. After giving informed consent, 12 affected individuals and nine unaffected family members were examined by neurologists and participated in the genetic study. A complete neurophysiologic evaluation was performed in all but one affected individual and in five unaffected family members (Subjects IV-1, IV-9, V-4, V-10, and V-12). A sural nerve biopsy was performed on two subjects (Subjects III-4 and III-6).

Linkage analysis. Genomic DNA was isolated from total blood samples by using a standard phenol-chloroform extraction. Individuals were genotyped by using the following highly polymorphic microsatellite markers: 1) for CMT2A on 1p35-p36: D1S160, D1S244, D1S503, D1S450, D1S2667, D1S434, D1S228, D1S489, and D1S170; 2) for CMT2B on 3q13-q22: D3S1769, D3S1744; and 3) for CMT2D on 7p14: D7S1808, D7S435.

Two-point linkage studies were performed by using the MLINK program of the FASTLINK computer package version 2.1. CMT2 was assessed in the linkage analysis as an autosomal dominant trait with a gene frequency of 1/10,000. Seven age-dependent penetrance classes were calculated from the family data, and a disease penetrance of $99.2 \%$ is reached at 50 years. The genetic order of markers is deduced from GeneMap'99 (http://gdbwww.ncbi.nlm.gov/genemap).

Results. Clinical characteristics. Clinical data are summarized in table 1. The initial complaint was progressive foot drop or foot weakness, and the patients could date the onset of the disease when foot problems began to interfere with normal activities. The mean age at onset was 19.7 years \pm 16 (SD). It should be noted, however, that all but one of the older patients reported a disease onset between the fourth and the fifth decade of life, whereas patients belonging to the fourth generation reported a disease onset late in the first decade. One older patient (Patient III-2) was wheelchair bound, and two other older subjects (Subjects III-4 and III-10) had postural tremor of the hands.

Motor and sensory nerve conduction studies are reported in table 1. Electromyography showed in the distal muscles mild signs of denervation with reduced recruitment patterns in all subjects.

The sural nerve biopsy showed a decreased number of myelinated fibers, especially large fibers, with rare onion 
bulbs; no significant myelin abnormalities were evident on teased-fiber analysis.

Molecular study. No mutations were detected in PMP22 and MPZ, nor was the $1.5 \mathrm{Mb}$ tandem CMT1A duplication in $17 \mathrm{p} 11.2-\mathrm{p} 12$ detected.

Pairwise lod scores for the used STR are summarized in table 2. Negative or nonsignificant lod scores were obtained in a two-point linkage analysis by using STR markers on chromosomes 3 (CMT2B) and 7 (CMT2D), whereas positive lod scores were obtained for D1S450, D1S2667, D1S434, and D1S228, with a maximum lod score of 3.11 at D1S2667 in the absence of recombinants. In the affectedonly analysis, we reached a lod score of 2.35 for D1S2667 (data not shown). Multipoint linkage analysis was performed to delineate the linkage region by using the most informative microsatellite markers D1S503-D1S2667D1S228 of chromosome 1, setting D1S503 at 0 cM. A maximum lod score of 3.29 is found at D1S2667.

The segregation and haplotype analysis of the nine STR is shown in the figure. The disease haplotype for the markers D1S160 to D1S170 is $3-3-4-2-5-1-3-1-4$, and is present in 10 patients and in one asymptomatic carrier (V-4), currently 7 years old, suggesting a reduced penetrance at that age. Recombinations are found in affected individuals IV-13 (with the most proximal marker D1S160) and III-4 (with the most distal marker D1S170). These recombinations reduce the disease haplotype to 3-4-2-5-1-3-1 for the markers D1S244-D1S50 threedimensional 1S450-D1S2667-D1S434-D1S228-D1S489, with D1S160 and D1S170 as the most proximal and distal flanking markers. We further observed recombination events in three unaffected relatives. A proximal recombi- nation occurred with marker D1S160 in individual IV-9 (aged 42 years). Recombination occurred with markers D1S160, D1S224, and D1S503 in V-12 (aged 19 years). A double-recombination event might have occurred in IV-1 (aged 47 years) with markers D1S160, D1S224, and D1S503 at the proximal side. With the distal markers, recombination occurred with D1S228, D1S489 and D1S170. The marker D1S450 was not informative. Unfortunately, genotyping of his deceased mother III-3 was not possible to confirm this event.

We are fully aware that the use of recombinations in unaffected relatives to further refine the CMT2A region is speculative because they still could develop the disease at an older age. In this family, however, the unaffected individuals who presented recombination events had no clinical or neurophysiologic evidence of CMT. Subject IV-1 was examined when he was 47 years old and, at this age, all affected individuals had already shown signs of CMT; moreover, the patients belonging to the same generation as IV-1 dated the onset of the disease in their first decade of life. On these grounds, we consider the possibility that Subject IV-1 may still develop the disease to be unlikely.

Discussion. Othmane et al. $^{2}$ assigned a CMT2A locus in the distal region of chromosome $1 \mathrm{p}$, between the markers D1S244 and D1S228. Since then, only two Japanese families linked to the CMT2A region have been reported, but none of these families has proved useful in better defining the candidate gene region. ${ }^{3}$

We report a large southern Italian CMT2A family

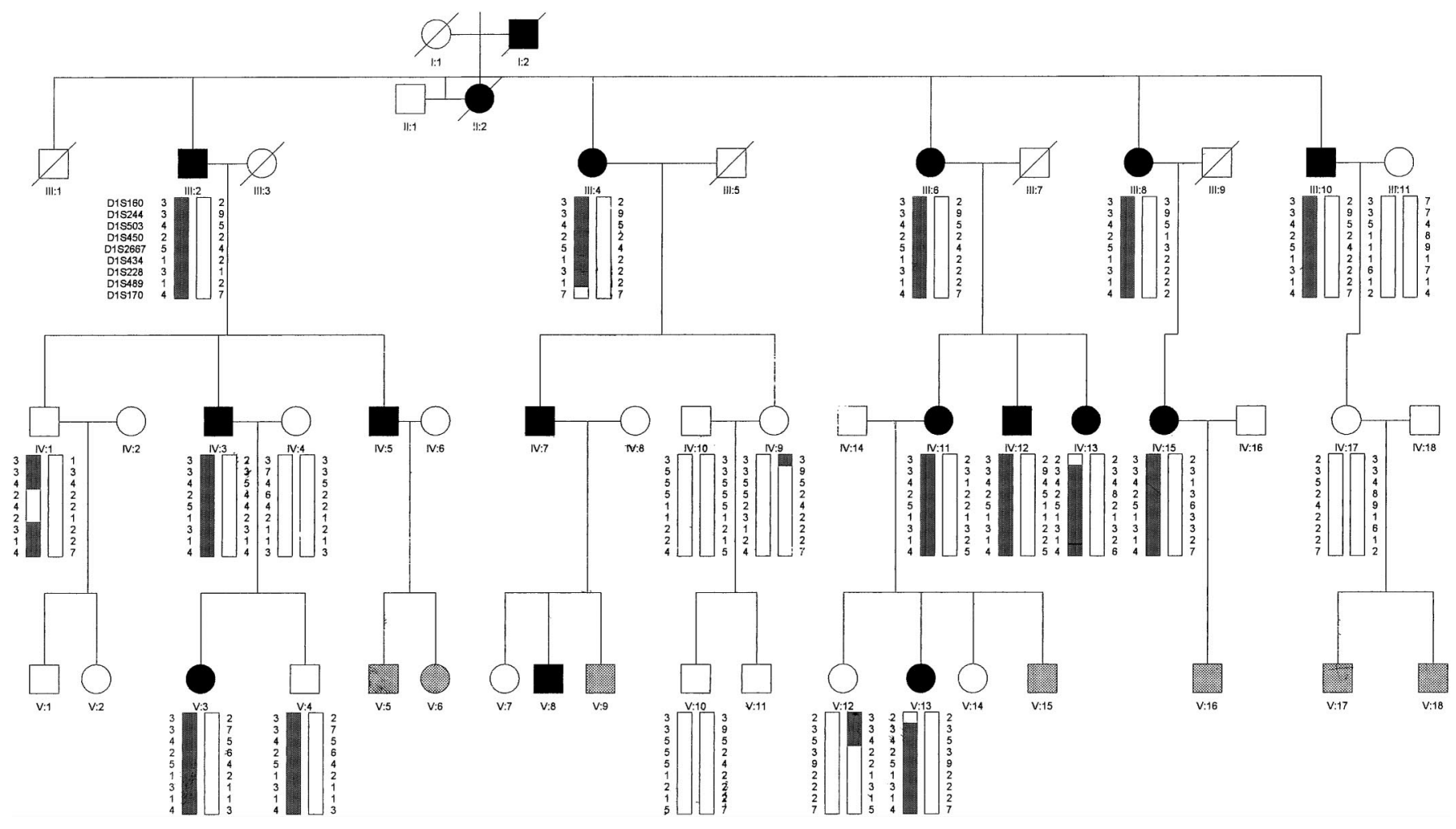

Figure. Pedigree of the Italian Charcot-Marie-Tooth type 2 (CMT2) family, showing the haplotypes of the patients. Circles = women; squares = men; slashed symbols = deceased individuals; filled symbols $=$ affected individuals; open symbols $=$ unaffected individuals; shaded symbols = disease status unknown; black bars = disease haplotype linked to CMT2A. 


\begin{tabular}{|c|c|c|c|c|c|}
\hline Patient/sex/age, y & $\begin{array}{l}\text { Age at } \\
\text { onset, y }\end{array}$ & Gait & $\begin{array}{c}\text { Atrophy and } \\
\text { weakness, UL/LL }\end{array}$ & $\begin{array}{l}\text { Tendon } \\
\text { reflexes, UL/ } \\
\text { knee/ankle }\end{array}$ & Pes cavus \\
\hline III-2/M/71 & 40 & Wheelchair & $\mathrm{Mo} / \mathrm{S}$ & $\mathrm{D} / \mathrm{A} / \mathrm{A}$ & + \\
\hline III-4/F/70 & 35 & Unilateral support & $\mathrm{Mi} / \mathrm{S}$ & $\mathrm{D} / \mathrm{A} / \mathrm{A}$ & + \\
\hline III-6/F/62 & 40 & Steppage & $\mathrm{Mi} / \mathrm{Mo}$ & $\mathrm{A} / \mathrm{A} / \mathrm{A}$ & + \\
\hline III-8/F/63 & 10 & Steppage & $\mathrm{Mi} / \mathrm{S}$ & $\mathrm{A} / \mathrm{A} / \mathrm{A}$ & + \\
\hline III-10/M/60 & 50 & Steppage & $\mathrm{Mi} / \mathrm{Mo}$ & N/D/A & + \\
\hline IV-3/M/42 & 8 & Steppage & Mi/Mo & N/D/A & + \\
\hline IV-11/F/38 & 9 & Steppage & $\mathrm{Mi} / \mathrm{Mo}$ & $\mathrm{D} / \mathrm{A} / \mathrm{A}$ & + \\
\hline IV-12/M/29 & 9 & Steppage & $\mathrm{Mi} / \mathrm{Mo}$ & $\mathrm{A} / \mathrm{A} / \mathrm{A}$ & + \\
\hline IV-13/F/28 & 8 & Steppage & Mi/Mo & $\mathrm{A} / \mathrm{A} / \mathrm{A}$ & + \\
\hline IV-15/F/27 & 10 & Steppage & $\mathrm{Mi} / \mathrm{Mo}$ & N/A/A & + \\
\hline V-3/F/11 & 1 & Steppage & N/Mo & N/D/A & + \\
\hline $\mathrm{V}-13 / \mathrm{F} / 17$ & 17 & Normal & $\mathrm{N} / \mathrm{Mi}$ & N/D/A & + \\
\hline
\end{tabular}

Boldface indicates abnormal values.

* CMAP amplitude was calculated peak to peak.

$\mathrm{UL}=$ upper limbs; LL = lower limbs; MNCV = motor nerve conduction velocity; CMAP = compound motor action potential; SNCV = sensory nerve conduction velocity; $\mathrm{SNAP}=$ sensory nerve action potential; $\mathrm{NV}=$ normal values; $\mathrm{N}=$ normal; $\mathrm{Mi}=$ mild; $\mathrm{Mo}=$ moderate; $\mathrm{S}=$ severe; $\mathrm{D}=$ decreased; $\mathrm{A}=$ absent; $\mathrm{ND}=$ not done; $\mathrm{NR}=$ no response.

linked to chromosome 1p35-p36. Using additional markers located between D1S244 and D1S228, we were able to refine the CMT2A region. We first obtained a lod score of 3.11 with D1S2667. Analysis of the disease haplotypes in affected individuals indicated proximal recombination with D1S160 and distal recombination with D1S170. Based on previously reported genetic data in two Japanese families ${ }^{3}$ and the recombination events in our Italian family, we could map the CMT2A gene between D1S503 and
D1S228, thus refining the CMT2A region by approximately $6 \mathrm{cM}$, from $16 \mathrm{cM}$ to $10 \mathrm{cM}$.

The clinical picture of this family was quite uniform and similar to that reported in the other CMT2A families, ${ }^{2,3}$ confirming intrafamily and interfamily uniformity of the electroclinical CMT2A phenotype. The CMT2A phenotype, however, is distinct from that observed in CMT2 families associated with $M P Z$ and $C x 32$ gene mutations. ${ }^{7,8}$ In these latter cases, NCV can be slightly reduced or nearly normal,

Table 2. Pair wise LOD scores for Charcot-Marie-Tooth disease type 2 versus chromosome 1p, $3 q$, and $7 p$

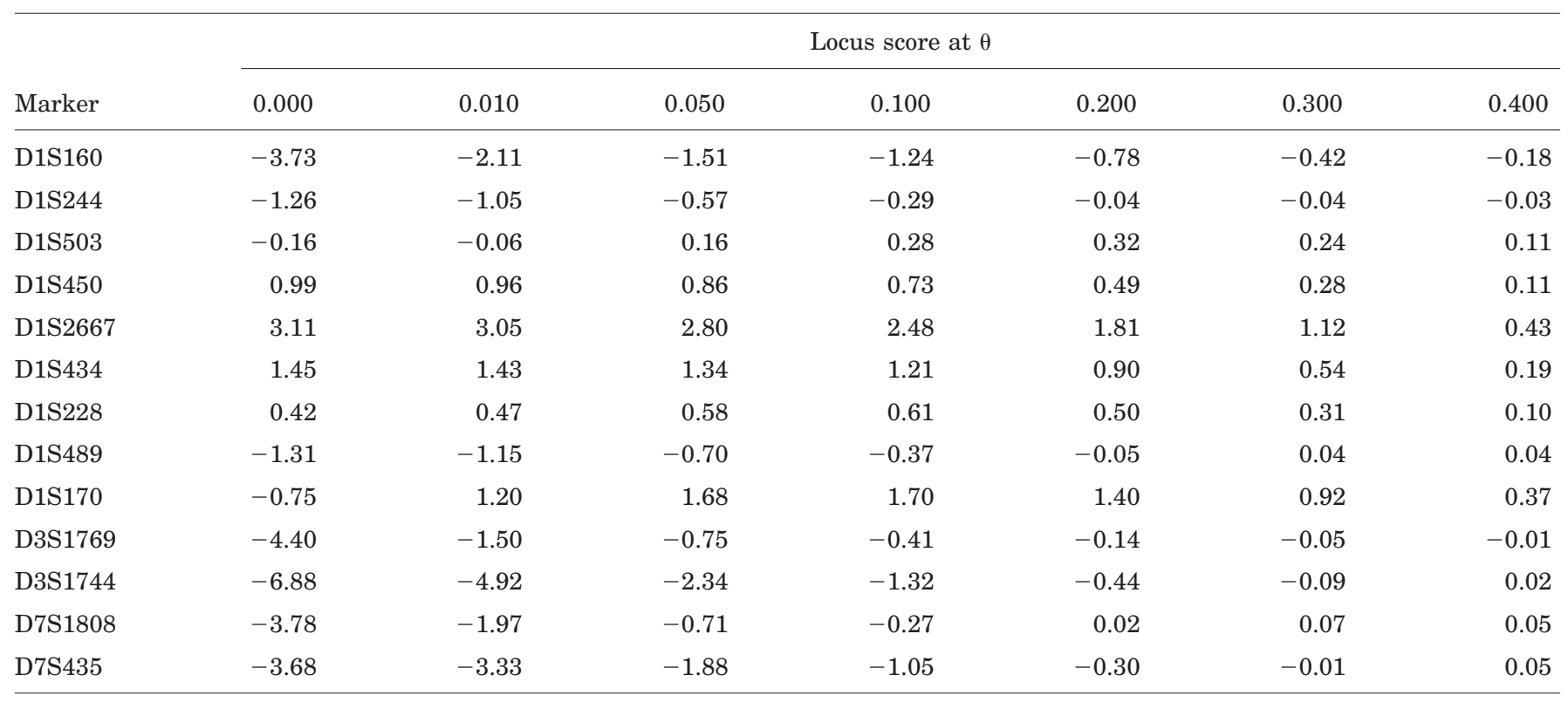




\begin{tabular}{|c|c|c|c|c|c|c|c|}
\hline \multicolumn{4}{|c|}{ Median nerve } & \multicolumn{2}{|c|}{ Peroneal nerve } & \multicolumn{2}{|c|}{ Sural nerve } \\
\hline $\begin{array}{l}\mathrm{MNCV}, \mathrm{m} / \mathrm{s} \\
(\mathrm{NV}>51)\end{array}$ & $\begin{array}{l}\mathrm{CMAP}, \mathrm{mV}^{*} \\
\quad(\mathrm{NV}>6)\end{array}$ & $\begin{array}{c}\mathrm{SNCV}, \mathrm{m} / \mathrm{s} \\
(\mathrm{NV}>41)\end{array}$ & $\begin{array}{l}\text { SNAP, uV } \\
(\mathrm{NV}>10)\end{array}$ & $\begin{array}{c}\mathrm{MNCV}, \mathrm{m} / \mathrm{s} \\
(\mathrm{NV}>44)\end{array}$ & $\begin{array}{c}\mathrm{CMAP}, \mathrm{mV}^{*} \\
(\mathrm{NV}>3)\end{array}$ & $\begin{array}{l}\mathrm{SNCV}, \mathrm{m} / \mathrm{s} \\
(\mathrm{NV}>34)\end{array}$ & $\begin{array}{r}\text { SNAP, uV } \\
(\mathrm{NV}>6)\end{array}$ \\
\hline ND & ND & ND & ND & ND & ND & ND & ND \\
\hline 55 & 25.7 & 38 & 21.3 & NR & NR & NR & NR \\
\hline 40 & 2.3 & 41 & 10.9 & 27 & 0.6 & NR & NR \\
\hline 54 & 1.8 & NR & NR & NR & NR & NR & NR \\
\hline 46 & 1.5 & 48 & 6.8 & 23 & 0.07 & NR & NR \\
\hline 54 & 9.9 & 40 & 20 & 41 & 0.4 & 30 & 8 \\
\hline 63 & 29.8 & 40 & 8.6 & 43 & 3.1 & 27 & 2.8 \\
\hline 59 & 14 & 34 & 6.8 & NR & NR & 28 & 5.6 \\
\hline 64 & 12.9 & 32 & 11 & NR & NR & 30 & 4.8 \\
\hline 57 & 8.9 & 44 & 3 & NR & NR & NR & NR \\
\hline 59 & 13.3 & 38 & 32.8 & 30 & 0.3 & 33 & 1.7 \\
\hline 59 & 13 & 38 & 28.4 & 51 & 18 & 33 & 6.2 \\
\hline
\end{tabular}

but in elderly patients the NCV may drop to 25 $\mathrm{m} / \mathrm{second}$. Thus, the NCV range is much broader than in our Southern Italian CMT2A family, and the lower limit is much lower. A sural nerve biopsy indicated a process of demyelination and remyelination besides axonal involvement. ${ }^{8}$

Finally, many genes are known to be located in the telomeric region of chromosome 1p; however, no obvious candidate genes have been identified. Vance $^{10}$ has previously screened synaptobrevin 3 , a synaptic vesicle protein that has an essential role in exocytosis. Subsequent DNA sequencing of the coding region indicated no mutations in CMT2A patients. ${ }^{10}$ We expect that our new CMT2A family will contribute further to the refinement of the CMT2A region and to identification of the causative gene for CMT2A.

\section{References}

1. Dyck PJ, Chance P, Lebo R, Carney JA. Hereditary motor and sensory neuropathies. In: Dyck PJ, Thomas PK, Lambert EH, eds. Peripheral neuropathy. 2nd ed. Philadelphia, PA: W.B. Saunders, 1993:1094-1136.
2. Othmane KB, Middleton LT, Loprest LJ, et al. Localization of a gene (CMT2A) for autosomal dominant Charcot-MarieTooth disease type 2 to chromosome $1 \mathrm{p}$ and evidence of genetic heterogeneity. Genomics 1993;17:370-375.

3. Saito M, Hayashi Y, Suzuki MD, et al. Linkage mapping of the gene for Charcot-Marie-Tooth disease type 2 to chromosome $1 \mathrm{p}$ (CMT2A) and the clinical features of CMT2A. Neurology 1997;49:1630-1635.

4. Kwon JM, Elliott JL, Yee W, et al. Assignment of a second Charcot-Marie-Tooth disease type 2 locus to chromosome 3q. Am J Hum Genet 1995;57:853-858.

5. Ionasescu V, Searby C, Sheffield VC, et al. Autosomal dominant Charcot-Marie-Tooth axonal neuropathy mapped on chromosome 7p (CMT2D). Hum Mol Genet 1996;5:1373-1375.

6. Dyck PJ, Litchy WJ, Minnerath S, et al. Hereditary motor and sensory neuropathy with diaphragm and vocal cord paresis. Ann Neurol 1994;5:608-615.

7. Marrosu MG, Vaccargiu S, Marrosu G, et al. Charcot-MarieTooth disease associated with mutation of the myelin protein zero gene. Neurology 1998;50:1397-1401.

8. De Jonghe P, Timmerman V, Ceuterick C, et al. The Thr124Met mutation in the peripheral myelin protein zero (MPZ) gene is associated with a clinically distinct CharcotMarie-Tooth phenotype. Brain 1999;122:281-290.

9. Mersiyanova IV, Perepelov AV, Polyakov AV, et al. A new variant of Charcot-Marie-Tooth disease type 2 is probably the result of a mutation in the Neurofilament-light gene. Am J Hum Genet 2000;67:37-46.

10. Vance JM. Charcot-Marie-Tooth disease type 2. Ann NY Acad Sci 1999;883:42-46. 


\section{Neurology}

\section{Clinical and genetic study of a large Charcot-Marie-Tooth type 2A family from southern Italy}

M. Muglia, M. Zappia, V. Timmerman, et al.

Neurology 2001;56;100-103

DOI 10.1212/WNL.56.1.100

This information is current as of January 9, 2001

\section{Updated Information \& Services}

References

Citations

Subspecialty Collections

Permissions \& Licensing

Reprints including high resolution figures, can be found at: http://n.neurology.org/content/56/1/100.full

This article cites 9 articles, 2 of which you can access for free at: http://n.neurology.org/content/56/1/100.full\#ref-list-1

This article has been cited by 3 HighWire-hosted articles: http://n.neurology.org/content/56/1/100.full\#\#otherarticles

This article, along with others on similar topics, appears in the following collection(s):

\section{All Genetics}

http://n.neurology.org/cgi/collection/all_genetics

Genetic linkage

http://n.neurology.org/cgi/collection/genetic_linkage

Peripheral neuropathy

http://n.neurology.org/cgi/collection/peripheral_neuropathy

Information about reproducing this article in parts (figures,tables) or in its entirety can be found online at:

http://www.neurology.org/about/about_the_journal\#permissions

Information about ordering reprints can be found online: http://n.neurology.org/subscribers/advertise

Neurology ${ }^{\circledR}$ is the official journal of the American Academy of Neurology. Published continuously since 1951, it is now a weekly with 48 issues per year. Copyright . All rights reserved. Print ISSN: 0028-3878. Online ISSN: 1526-632X.

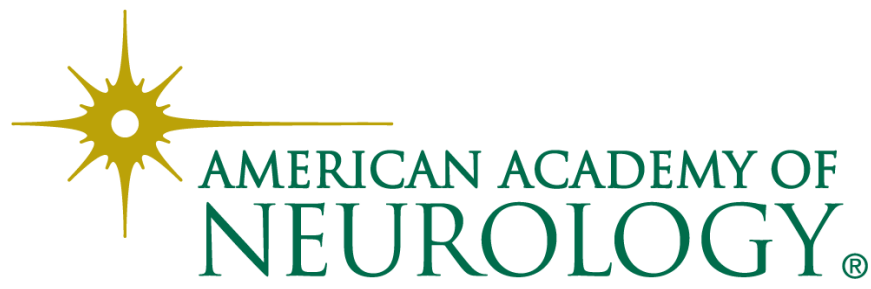

